\title{
Production of cellulase from Aspergillus niger and Trichoderma reesei mixed culture in carboxymethylcellulose medium as sole carbon
}

\author{
DIA SEPTIANI ${ }^{1, \bullet}$, HERMAN SURYADI $^{2}$, ABDUL MUN'IM ${ }^{1,3, v \vee}$, WIBOWO MANGUNWARDOYO ${ }^{4}$ \\ ${ }^{1}$ Pharmaceutical Sciences Graduate Program, Faculty of Pharmacy, Universitas Indonesia. Kampus UI, Depok 16424, West Java, Indonesia. \\ Tel.: +62-21-7270031, Fax.: +62-21-7863433, `email: dia.septiani@gmail.com \\ ${ }^{2}$ Drug Delivery Laboratory, Faculty of Pharmacy, Universitas Indonesia. Kampus UI, Depok 16424, West Java, Indonesia \\ ${ }^{3}$ Laboratory of Pharmacognosy-Phytochemistry, Faculty of Pharmacy, Universitas Indonesia. Kampus UI, Depok 16424, West Java, Indonesia. \\ Tel.: +62-21-7270031, Fax.: +62-21-7863433, "email: munim@ farmasi.ui.ac.id \\ ${ }^{4}$ Departement of Biology, Faculty of Mathematical Sciences, Universitas Indonesia. Kampus UI, Depok 16424 West Java, Indonesia
}

Manuscript received: 10 September 2019. Revision accepted: 15 November 2019.

\begin{abstract}
Septiani D, Suryadi H, Mun'im A, Mangunwardoyo W. 2019. Production of cellulase from Aspergillus niger and Trichoderma reesei mixed culture in carboxymethylcellulose medium as sole carbon. Biodiversitas 20: 3539-3544. Cellulase is one of hydrolytic enzymes that breakdown cellulose into glucose. Cellulases are promising to be applied in natural products which may improve the yield of bioactive in plant extract through cellulose depolymerization. Cellulases from mixed culture of Aspergillus niger and Trichoderma reesei can produce a high cellulase activity because of the synergism activity among endoglucanase, exoglucanase, and also $\beta$-glucoside. Cellulase production and partial purification of monoculture and mixed culture (1:1) of these fungi on carboxymethylcellulose media were investigated in this study. Total cellulase activity was measured by filter paper assay followed by protein estimation with Bradford method. The crude extract of Aspergillus niger monoculture has the highest cellulase activity $(0.131 \mathrm{U} / \mathrm{mL}, \mathrm{P}<005)$ followed by mixed culture $(0.109 \mathrm{U} / \mathrm{mL})$ and Trichoderma reesei $(0.106 \mathrm{U} / \mathrm{mL})$. The cellulase activity of partially purified cellulase from mixed culture significantly increased $(0.335,0.348,0.374 \mathrm{U} / \mathrm{mL}, \mathrm{P}<0.05)$ compared to crude extract along with stepwise addition of ammonium sulfate. Cellulase activity of mixed culture at $80 \%$ ammonium sulfate increase up to 2.238 -fold and showed highest value $(\mathrm{P}<0.05)$ compared to monocultures. In conclusion, combination of Aspergillus niger and Trichoderma reesei fungi in carboxymethyl cellulose media followed by $80 \%$ ammonium sulfate precipitation can be a promising cellulase production with high cellulase activity.
\end{abstract}

Keyword: Aspergillus niger, cellulase, carboxymethyl cellulose, mixed culture, Trichoderma reesei

\section{INTRODUCTION}

Cellulase is a group of hydrolytic enzymes which abundant in nature (Kaur and Joshi 2015). Cellulase is a trivial name of ${ }_{\beta}$-1,4-glucan-4-glucanohydrolase (EC.3. 2. 1. 4). Cellulase enzyme can hydrolyze $\beta^{-1,4-g l u c o s i d e}$ chain in cellulose, cellodextrin, cellobiose, and other cellulose derivative (Zhang and Zhang 2013). Cellulose, as a substrate of cellulase, constructed in linear forms. It contains units of anhydride glucose and linked tightly one another at first (C1) and four (C4) carbon of glucose units that contribute to a tight structure called a $\beta$-1,4-glucoside chain (Kaur and Joshi 2015). Cellulase breakdown of the cellulose structure by involving synergistic action of cellulolytic enzyme complexes: endo- $\beta$-glucanase, exo- $\beta$ glucanase, and ${ }_{\beta}$-glucosidase in certain quantity (Jamil et al. 2009).

Microorganisms such as bacteria and fungi are cellulase producers (Zhao et al. 2018). Aerobic fungi of the Ascomycetes, Aspergillus sp., and Trichoderma sp. have received significant attention as cellulose-degrading with high cellulase activity (Zhao et al. 2018). Furthermore, its extracellular cellulase model with high yield made it easy to produce commercially (Jagavati et al. 2012).

Trichoderma reesei more often produces large quantities of endo- $\beta$-glucanase and exo- $\beta$-glucanase, rather than ${ }_{\beta}$-glucoside (Diana et al. 2012). Meanwhile, Aspergillus niger found to be the highest producers of $\beta^{-}$ glucoside and endo- $\beta$-glucanase (Kassim 1982). The consortium of Trichoderma reesei and Aspergillus niger will be promising to produce synergistic action of highly extracellular cellulase activity.

A cellulase activity can be measured by observing the clear zone around colony in solid medium, meanwhile, filter paper assay (FPase) measured the total cellulase activity in broth medium through glucose reduction from Whatman paper (Dashtban et al. 2010). Carboxymethylcellulose (CMC) is a soluble cellulose derivate which easily degraded by many organisms. CMC is a useful carbon source of both liquid and solid medium for cellulase production, and the hydrolysis of CMC also easy to determine by chromogenic reagent Congo red (Johnsen and Krause 2014).

The main challenge for abundant cellulase from fungi is to utilize them in plant extraction to degrade cellulose from natural products. Cellulase from fungi has a bright prospect in future natural product extraction that can provide high yield of bioactive, less time extraction, and reduce extraction cost. The purpose of this study is to obtain the higher cellulase activity from mixed culture of Aspergillus niger and Trichoderma reesei than monocultures using carboxymethyl cellulose as sole carbon medium. 


\section{MATERIALS AND METHODS}

Pure isolate of Aspergillus niger (UICC 371) and Trichoderma reesei (IPBCC) were obtained from IPB Culture Collection, Bogor, and Universitas Indonesia Culture Collection, Depok respectively. The fungi were recultured and maintained on potato dextrose agar (Difco) tube at $28^{\circ} \mathrm{C}$. The partially purified enzyme with high cellulase activity from this study deposited in dry powder form to extend its shelf life. The instruments used were autoclave (Tomy, Japan), oven (WTB Binder, Germany), analytical balance (Acculab, USA), hotplate stirrer (Corning, USA), pH meter (Hanna, USA), centrifugation (Kubota, Japan), incubator (Memmert, Germany), microscope (Micromax, USA), air shaking incubator (Heidolph, Germany), laminar airflow (Kubota, Japan), vortex, haemacytometer (Improved Neubauer, Germany), UV-Vis spectrophotometer (Shimadzu UV-1601, Japan), freeze dryer, ose, volumetric pipette and other glasswares commonly used in laboratories. All the chemicals were analytical grade, such as glucose (Merck, Germany), sodium carboxymethyl cellulose (CMC), sodium hydroxide (Bratachem, Indonesia), nitric acid (Bratachem, Indonesia), urea (Merck, Germany), ammonium sulphate (Merck, Germany), potassium dihydrogen phosphate (Merck, Germany), tween 80 (Merck, Germany), sodium potassium tartrate (Merck, Germany), magnesium sulfate heptahydrate (Meck, Germany), iron (II) sulfate heptahydrate (Merck, Germany), yeast extract (Difco, USA), bacteriological agar (Merck, Germany), dinitrosalicylic acid (Sigma, USA), sodium chloride (Merck), congo red (Sigma, USA), bovine serum albumin (Sigma, Germany), Bradford dye reagent concentrate (Bio-Rad, USA), Whatman paper no. 1, aquadest, and aquabidest.

\section{Screening of cellulase activity based on clear zone}

Fungi isolates, A. niger, and T. reesei, as monoculture stock were cultured on potato dextrose agar tube and incubated at $28^{\circ} \mathrm{C}$ for 3 days. After 3 days incubation, each fungal isolate was subcultured on agar medium plates that contained $1 \%$ carboxymethylcellulose, $0.1 \mathrm{~g} \mathrm{NaNO}_{3}, 0.05$ g yeast extract, $0,1 \mathrm{~g} \mathrm{KH}_{2} \mathrm{PO}_{4}, 0.1 \mathrm{~g} \mathrm{MgSO}_{4} .7 \mathrm{H}_{2} \mathrm{O}, 0.1 \mathrm{~g}$ glucose (Murti et al. 2018). The plates were incubated at $28^{\circ} \mathrm{C}$ for 3 days and screened for cellulase production at least twice. The clear zone was observed by stained the plates with $1 \%$ congo red solution for 30 minutes followed by destained with $1 \mathrm{M} \mathrm{NaCl}$ solution for 20 minutes. The clear zone was determined by the ability of fungi to produce cellulase. The clear zone measured by ratio of clear zone diameter and colony diameter $(\mathrm{cm})$ (Khokhar et al. 2012).

\section{Cellulase production}

Preparation of pre-culture and production medium

The media for cellulase enzyme production, in this research, were preculture and production medium, which added with $\mathrm{CMC}$ as sole carbon. The preculture and production medium contain $200 \mathrm{mg}$ yeast extract, $750 \mathrm{mg}$ urea, $280 \mathrm{mg}\left(\mathrm{NH}_{4}\right)_{2} \mathrm{SO} 4,400 \mathrm{mg} \mathrm{KH}_{2} \mathrm{PO}_{4}, 150 \mathrm{mg}$ $\mathrm{MgSO}_{4} .7 \mathrm{H}_{2} \mathrm{O}, 1 \mathrm{mg} \mathrm{FeSO} 4.7 \mathrm{H}_{2} \mathrm{O}$, diluted in $0.1 \mathrm{M}$ acetic acid buffer $200 \mathrm{~mL}$ (Murti et al. 2018). Preculture and production medium contain $\mathrm{CMC}$ at 0.5 and $2.5 \%$ concentration, respectively. The higher concentration of CMC in production media than preculture media was to enrich media in order to produce high yield of cellulase.

\section{Preparation of inoculum}

The inoculum of $A$. niger and $T$. reesei were used at a density $1 \times 10^{8} \mathrm{cfu} / \mathrm{mL}$ and observed by haemacytometer counting chamber under light microscope. Each fungi inoculum was a spore suspension obtained from harvested the isolate in sterile aquabidest and $0.1 \%$ tween 80 (Murti et al. 2018).

\section{Production of cellulase enzyme}

Two $\mathrm{mL}$ of $A$. niger and $T$. reesei inoculums were inoculated into $500 \mathrm{~mL}$ Erlenmeyer flasks containing 100 $\mathrm{mL}$ pre-culture medium. There were 3 sets of Erlenmeyer flasks, contain monoculture of A. niger and T. reesei and mixed culture (1:1) fungal inoculum. The flasks were incubated for 48 hours in shaker incubator at $28^{\circ} \mathrm{C} 150 \mathrm{rpm}$ for inoculum development before they were used for cellulase production in production medium (Zhao et al. 2018). After 48 hours incubation, about ten milliliters of preculture media were inoculated into 3 sets of $200 \mathrm{~mL}$ production media in $500 \mathrm{~mL}$ Erlenmeyer flasks. The production media were stirred in incubator shaker at 150 rpm $28^{\circ} \mathrm{C}$ for 72 hours.

\section{Cellulase extraction}

Tween $80(0.1 \%)$ was added to production media, then were aliquoted into $15 \mathrm{~mL}$ centrifuge tubes. The tubes were centrifuged at $4^{\circ} \mathrm{C} 3000 \mathrm{rpm}$ for 10 minutes (Murti et al. 2018). Supernatant was collected as crude extract of cellulase enzyme and used for cellulase assay (Ghose 1987).

\section{Purification of cellulase enzyme}

Purification of cellulase enzymes was carried out by salting out process with ammonium sulfate (Ikeda et al. 2014). Proteins of enzymes were sequentially precipitated from $30 \mathrm{~mL}$ of the crude extract by stepwise addition of solid ammonium sulfate from 40,60 , to 80 percent saturation and followed by overnight incubation at $4^{\circ} \mathrm{C}$. On the next day, the solution was centrifuged at $4^{\circ} \mathrm{C} 4500 \mathrm{rpm}$ for 20 minutes. The pellet obtained after centrifugation was resuspended in $0.05 \mathrm{M}$ acetate buffer $\mathrm{pH} 5.5$ up to $1 / 5$ filtrate volume. Aliquots of precipitated fractions, as partially purified cellulase enzymes, were analysed for its cellulase activity by FPase (Ghose 1987) and its protein contents by Bradford method (Bradford 1976). The total cellulase activity of partially purified cellulase was compared to crude extract.

\section{Total cellulase activity of filter paper assay (FPase)}

Cellulase activity was measured by filter paper assay used Whatman filter paper no. 1 in a size of $1 \times 6 \mathrm{~cm}$ strip as standard substrate (Dashtban et al. 2010; Ghose 1987). FPase assay was performed by add $0.5 \mathrm{~mL}$ cellulase enzymes into tube filled with one filter paper $(50 \mathrm{mg})$ and 1 
mL $0.05 \mathrm{M}$ sodium citrate. The concentration of glucose was estimated by dinitrosalysilic acid (DNS) reagent (Ghose 1987). About $2 \mathrm{mg}$ glucose equivalents added to the tube and boiled for 60 minutes at $50^{\circ} \mathrm{C}$. After that, $1 \%$ DNS solution was added and boiled for 5 minutes to stop the enzymatic reaction. The absorbance of solution was measured by UV-Vis spectrophotometer at $540 \mathrm{~nm}$ wavelength. Total fungal cellulase activity was estimated by a standard equation compared to the glucose calibration curve. The total cellulase activity of FPase was determined in the standard IUPAC procedure and expressed as an international unit (IU) in $\mathrm{U} / \mathrm{mL}$ as one micromole of glucose equivalents to per minute of culture filtrate under assay conditions (Ghose 1987).

\section{Total protein content of enzyme}

The protein content in crude extract and partially purified cellulase enzyme were determined by Bradford method (Bradford 1976). Protein assay was prepared by diluted one part of concentrate dye reagent with 4 parts aquabidest and filtered with Whatman \#1 filter paper to remove particulates. Bovine serum albumin (BSA) was used as standard protein and diluted to 5 different concentrations $(0.01,0.02,0.04,0.06,0.08 \mathrm{mg} / \mathrm{mL})$. About two $\mathrm{mL}$ of dye reagent mixed with different concentrations of standard protein, and incubated for 5 minutes at room temperature. The absorbance of solutions was measured under UV-Vis spectrophotometer at $595 \mathrm{~nm}$ (Bradford 1976). The absorbance of the standard protein with the concentration was plotted to construct a calibration curve. The total protein content in cellulase crude extract and partially purified cellulase were determined by mixed $1 \mathrm{~mL}$ of each sample with $2 \mathrm{~mL}$ dye reagent in tube then incubated for 5 minutes at room temperature. The absorbance of samples was measured using UV-Vis spectrophotometer at $595 \mathrm{~nm}$. The protein content in samples was measured by substituted the absorbance data into a calibration curve.

\section{Data analysis}

Total cellulase activity of mixed culture compares to monoculture of $A$. niger and T. reesei was done by onewayANOVA followed by Least Significance Different (LSD) to assess the significant differences $(\mathrm{P}<0,05)$. Meanwhile, the total cellulase activity between crude extract and partially purified in each group was analyzed by a paired $t-$ test. All data were analyzed by Statistical Package for Social Sciences (SPSS) software ver. 24.

\section{RESULTS AND DISCUSSION}

\section{Screening of cellulase activity based on clear zone}

The ability of $A$. niger and $T$. reesei grew in CMC solid medium form a clear zone around colony that indicated the cellulolytic activity (Figure 2). The growth of colony was observed at the end of 5 days incubation. After day 5, the plates were stained with $1 \%$ congo red to observe clear zone of hydrolysis. The clear zone of CMC hydrolysis was $0.45 \mathrm{~cm}$ on $A$. niger and 0.1 on $T$. reesei. The result indicates that $A$. niger (UICC 371) and T. reesei (IPBCC) were capable of utilized CMC and produce cellulase. Their cellulolytic activity was further evaluated by inoculating its spore suspension to cellulase production broth medium supplemented by CMC as sole carbon.

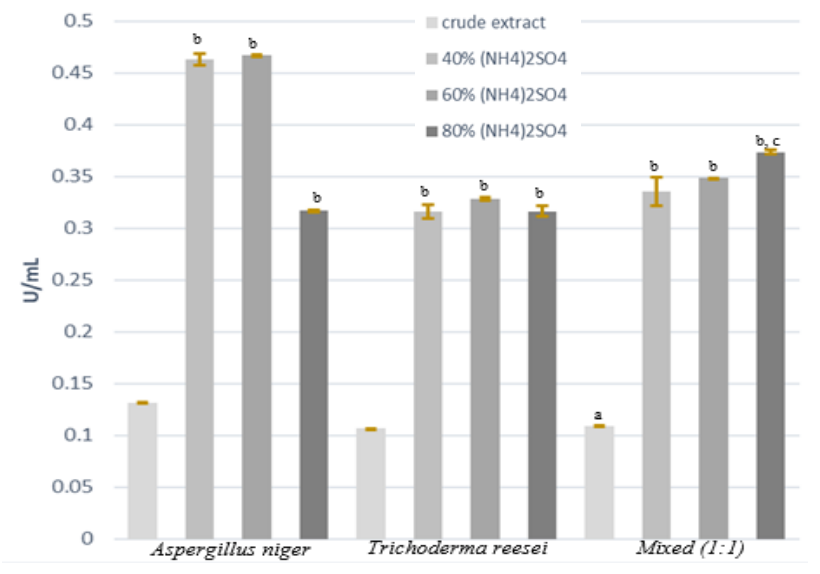

Figure 3. Total FPase cellulase activity in crude extract and partially purified cellulase. Note: ${ }^{a, c}$ significant difference compared to monocultures $(\mathrm{P}<0,05)$ by ANOVA, b significant difference compared to crude extract $(\mathrm{P}<0,05)$ by paired t-test
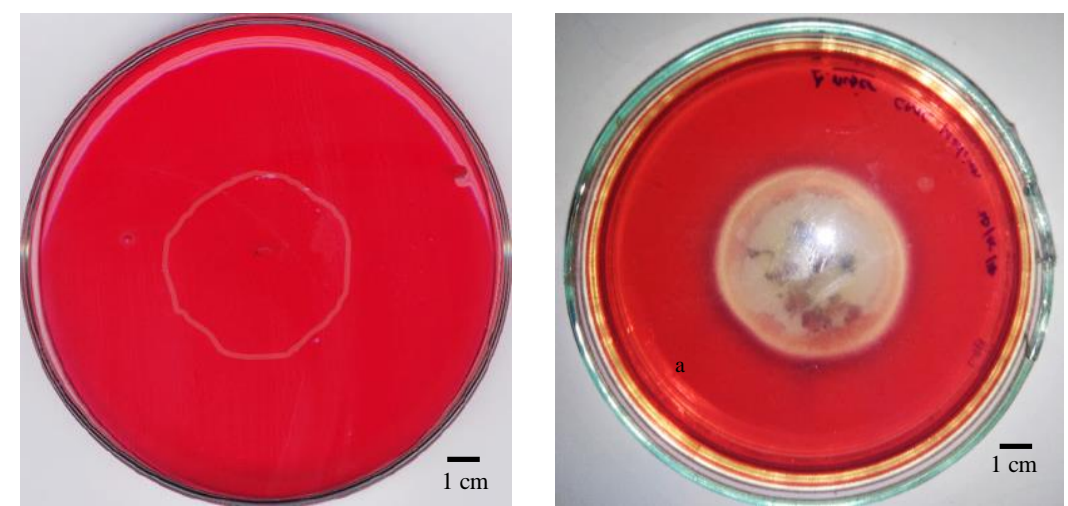

Figure 2. The clear zone of Aspergillus niger (right) and Trichoderma reesei (left) in CMC medium agar, 7 days incubation at $28^{\circ} \mathrm{C}$ 


\section{Total cellulase activity of Filter paper assay (FPase)}

Total cellulase activity in crude extract and partially purified cellulase at different concentration of ammonium sulfate $\left(\left(\mathrm{NH}_{4}\right)_{2} \mathrm{SO}_{4}\right)$ presented in Table 1 and Figure 3. Total cellulase activity of crude extract from mixed culture (1:1) significantly different $(\mathrm{P}<0,05)$ to monocultures (Table 1). The result showed significant difference between and within groups of monocultures and mixed culture by oneway-ANOVA test followed by LSD test (Table 2). The positive mean difference values in A-T and A-M (Table 2) indicated that cellulase activity produced by A. niger, $T$. reesei, and mixed culture was significantly different. A crude extract of $A$. niger produced highest glucose concentration with the highest FPase enzymatic activity $(0,131 \mathrm{U} / \mathrm{mL})$ followed by mixed culture (1:1) $(0,109$ $\mathrm{U} / \mathrm{mL}$ ) and monoculture of $T$. reesei $(0,106 \mathrm{U} / \mathrm{mL})$ (Table 1) at $72 \mathrm{~h}$ of incubation. We conclude that there was significant difference $(\mathrm{P}<0,05)$ in total FPase activity between crude extract and partially purified enzyme along with ammonium sulfate addition. Enzyme from monoculture of $A$. niger showed the highest cellulase activity compared to others.

\section{Purification of cellulase enzyme}

FPase cellulase activity of partially purified enzymes was significantly difference $(\mathrm{P}<0.05)$ compared to crude extract in all groups (Table 1 and 3). The partially purified enzymes of A. niger, T. reesei, and mixed culture were higher than crude extract. Total cellulase activity increase along with step addition of ammonium sulfate saturation up to $60 \%$. The test showed positive $t$ values for all pair groups indicated the cellulase activities after precipitated were highly different compared with the crude extract
(Table 3). An addition of $80 \%$ ammonium sulfate saturation in mixed culture was improved the cellulase activity significantly compared to monocultures (Table 4).

Cellulase purification by $80 \%$ ammonium sulfate saturation improved cellulase activity up to 2.238 folds compare to initial activity of crude enzyme (Table 5). The increase in total cellulase activity and specific activity were observed at $0.378 \mathrm{U} / \mathrm{mL}$ and $15.768 \mathrm{U} / \mathrm{mg}$ respectively. The specific activity of enzyme was measured by dividing the cellulase activity with protein content in enzyme (Nema et al. 2016). The protein contents were determined by Bradford method which compare to the calibration curve of BSA as standard (Bradford 1976). The less protein content at $80 \%$ ammonium sulfate saturation was inversely proportional to the total cellulase activity (Table $5)$.

\section{Discussion}

There was few previous research that had been carried out using combination of A. niger and T. reesei as cellulase producers in different strain, substrates, and cellulase assay. The results of this research showed that FPase cellulase activity in mixed culture (1:1) of A. niger and T. reesei was $0.109 \mathrm{U} / \mathrm{mL}$. The cellulase activity in mixed culture was closed compare to previous research by Jagavati et al. (2012) with FPase of $0.24 \mathrm{U} / \mathrm{mL}$ in mixed culture of Aspergillus sp. And Trichoderma sp. isolated from degrading wood (with ratio 2:1). Lower FPase activity in this research due to differences in substrates, ratio of fungi, and incubation time during cellulase production (fermentation). All these factors must be at optimum conditions (Jagavati et al. 2012).

Table 1. Total FPase cellulase activity of monocultures and mixed culture (1:1) in crude extract and partially purified cellulase with a varying saturation level of ammonium sulfate

\begin{tabular}{lccc}
\hline \multirow{2}{*}{ Description } & \multicolumn{2}{c}{ Total cellulase activity $(\mathrm{U} / \mathrm{mL})$} \\
& \multicolumn{3}{c}{ Means \pm SD } \\
\cline { 2 - 4 } & Aspergillus niger & Trichoderma reesei & Mixed culture (1:1) \\
\hline Crude extract & $0.131 \pm 0.00025^{\mathrm{a}}$ & $0.106 \pm 0.00025$ & $0.109 \pm 0.0004$ \\
$\left(\mathrm{NH}_{4}\right)_{2} \mathrm{SO}_{4} 40 \%$ & $0.463 \pm 0.00806^{\mathrm{b}}$ & $0.317 \pm 0.00933^{\mathrm{b}}$ & $0.335 \pm 0.01958^{\mathrm{b}}$ \\
$\left(\mathrm{NH}_{4}\right)_{2} \mathrm{SO}_{4} 60 \%$ & $0.467 \pm 0.00127^{\mathrm{b}}$ & $0.328 \pm 0.00247^{\mathrm{b}}$ & $0.348 \pm 0.00049^{\mathrm{b}}$ \\
$\left(\mathrm{NH}_{4}\right)_{2} \mathrm{SO}_{4} 80 \%$ & $0.317 \pm 0.00134^{\mathrm{b}}$ & $0.316 \pm 0.00749^{\mathrm{b}}$ & $0.374 \pm 0.00289^{\mathrm{b}, \mathrm{c}}$ \\
\hline
\end{tabular}

Note: ${ }^{a}$ c significant difference compared to crude extract in other group $(\mathrm{P}<0.05)$ by ANOVA, ${ }^{\mathrm{b}}$ significant difference compared to crude extract $(\mathrm{P}<0.05)$ by paired $t$-test

Table 2. Statistical evaluation (Oneway-ANOVA and LSD test) of cellulase activity in monoculture and mixed culture crude extract of Trichoderma reesei and Aspergillus niger at 95\% confidence

\begin{tabular}{|c|c|c|c|c|c|}
\hline & Sum of squares & Df & Mean square & $\mathbf{F}$ & Sig. \\
\hline Between groups & 0.001 & 2 & 0.001 & 5745.799 & $0.000 *$ \\
\hline Within groups & 0.000 & 6 & 0.000 & & \\
\hline \multirow[t]{2}{*}{ Total } & 0.001 & 8 & & & \\
\hline & Mean difference & Standard error & Sig. & Lower bound & Upper bound \\
\hline A-T & 0.0246 & 0.0002 & $0.000 *$ & 0.0240 & 0.0252 \\
\hline A-M & 0.0219 & 0.0002 & $0.000 *$ & 0.02133 & 0.0225 \\
\hline T-A & -0.0246 & 0.0002 & $0.000 *$ & -0.0252 & -0.0240 \\
\hline T-M & -0.0026 & 0.0002 & $0.000 *$ & -0.0032 & -0.0020 \\
\hline M-A & -0.0219 & 0.0002 & $0.000 *$ & -0.0225 & -0.0213 \\
\hline M-T & -0.0026 & 0.0002 & $0.000 *$ & 0.0020 & -0.0032 \\
\hline
\end{tabular}


Note: *Sig. < 0,05, significant difference; A: A. niger crude enzyme; T: T. reesei crude enzyme; M: Mixed culture (1:1) crude enzyme Table 3. Statistical evaluation (paired t-test) of cellulase production and purification by mixed culture of $T$. reesei and A. niger with monocultures at $95 \%$ confidence

\begin{tabular}{lcccccccc}
\hline & Mean & $\begin{array}{c}\text { Standard } \\
\text { deviation }\end{array}$ & $\begin{array}{c}\text { Standard } \\
\text { error means }\end{array}$ & Lower & Upper & t & df & Sig. (2-tailed) \\
\hline Pair 1 & 0.3322 & 0.0054 & 0.0031 & 0.3187 & 0.3457 & 105.592 & 2 & $0.000^{*}$ \\
Pair 2 & 0.3356 & 0.0011 & 0.0006 & 0.3327 & 0.3385 & 505.533 & 2 & $0.000^{*}$ \\
Pair 3 & 0.1855 & 0.0007 & 0.0004 & 0.1837 & 0.1872 & 458.645 & 2 & $0.000^{*}$ \\
Pair 4 & 0.2100 & 0.0063 & 0.0036 & 0.1942 & 0.2258 & 57.294 & 2 & $0.000^{*}$ \\
Pair 5 & 0.2217 & 0.0020 & 0.0011 & 0.2167 & 0.2266 & 191.485 & 2 & $0.000^{*}$ \\
Pair 6 & 0.2099 & 0.0055 & 0.0032 & 0.1961 & 0.2237 & 65.521 & 2 & $0.000^{*}$ \\
Pair 7 & 0.2260 & 0.0134 & 0.0077 & 0.1926 & 0.2594 & 29.112 & 2 & $0.001 *$ \\
Pair 8 & 0.2394 & 0.0007 & 0.0004 & 0.2375 & 0.2413 & 543.059 & 2 & $0.000^{*}$ \\
Pair 9 & 0.2644 & 0.0016 & 0.0009 & 0.2603 & 0.2685 & 277.576 & 2 & $0.000^{*}$ \\
\hline
\end{tabular}

Note: $*$ Sig. $(2$ tailed) $<0,05$, significant difference.

Pair 1: Aspergillus niger $40 \%\left(\mathrm{NH}_{4}\right)_{2} \mathrm{SO}_{4}$ precipitation: Aspergillus niger crude enzyme

Pair 2: Aspergillus niger $60 \%\left(\mathrm{NH}_{4}\right)_{2} \mathrm{SO}_{4}$ precipitation: Aspergillus niger crude enzyme

Pair 3: Aspergillus niger $80 \%\left(\mathrm{NH}_{4}\right)_{2} \mathrm{SO}_{4}$ precipitation: Aspergillus niger crude enzyme

Pair 4: Trichoderma reesei $40 \%\left(\mathrm{NH}_{4}\right)_{2} \mathrm{SO}_{4}$ precipitation: Trichoderma reesei crude enzyme

Pair 5: Trichoderma reesei $60 \%\left(\mathrm{NH}_{4}\right)_{2} \mathrm{SO}_{4}$ precipitation: Trichoderma reesei crude enzyme

Pair 6: Trichoderma reesei $80 \%\left(\mathrm{NH}_{4}\right)_{2} \mathrm{SO}_{4}$ precipitation: Trichoderma reesei crude enzyme

Pair 7: Mixed culture $40 \%\left(\mathrm{NH}_{4}\right)_{2} \mathrm{SO}_{4}$ precipitation: Mixed culture crude enzyme

Pair 8: Mixed culture $60 \%\left(\mathrm{NH}_{4}\right)_{2} \mathrm{SO}_{4}$ precipitation: Mixed culture crude enzyme

Pair 9: Mixed culture $80 \%\left(\mathrm{NH}_{4}\right)_{2} \mathrm{SO}_{4}$ precipitation: Mixed culture crude enzyme

Table 4. Statistical evaluation (Oneway-ANOVA and LSD test) of partially purified cellulase at $80 \%$ saturation of ammonium sulfate

\begin{tabular}{lccccc}
\hline & Sum of squares & df & Mean square & F & Sig. \\
\hline Between groups & 0.007 & 2 & 0.003 & 294.475 & $0.000^{*}$ \\
Within groups & 0.000 & 6 & 0.000 & & \\
Total & 0.007 & 8 & & & \\
\hline
\end{tabular}

\begin{tabular}{lccccc}
\hline & Mean difference & Standard error & Sig. & Lower bound & Upper bound \\
\hline A-T & 0.0001 & 0.0027 & 0.953 & -0.0064 & 0.0068 \\
A-M & -0.0570 & 0.0027 & $0.000^{*}$ & -0.0636 & -0.0503 \\
T-A & -0.0001 & 0.0027 & 0.953 & -0.0068 & 0.0064 \\
T-M & -0.0571 & 0.0027 & $0.000^{*}$ & -0.0638 & -0.0505 \\
M-A & 0.0570 & 0.0027 & $0.000^{*}$ & 0.0503 & 0.0636 \\
M-T & 0.0571 & 0.0027 & $0.000^{*}$ & 0.0505 & 0.0638 \\
\hline
\end{tabular}

Note: *Sig. < 0,05, significant difference; A: Aspergillus niger partially purified enzyme; T: Trichoderma reesei partially purified enzyme; M: Mixed culture (1:1) partially purified enzyme

Table 5. Purification of cellulase in mixed culture of A. niger and T. reesei at 40, 60, and $80 \%$ saturation of ammonium sulphate

\begin{tabular}{lccccc}
\hline Steps & $\begin{array}{c}\text { X glucose } \\
(\mathbf{m g} / \mathbf{m L})\end{array}$ & $\begin{array}{c}\text { Total cellulase } \\
\text { activity }(\mathbf{U} / \mathbf{m L})\end{array}$ & $\begin{array}{c}\text { Protein content } \\
(\mathbf{m g} / \mathbf{m L})\end{array}$ & $\begin{array}{c}\text { Specific activity } \\
\text { (U/mg) }\end{array}$ & $\begin{array}{c}\text { Purification } \\
\text { (fold) }\end{array}$ \\
\hline Crude extract & 0.590 & 0.109 & 0.015 & 7.045 & 1 \\
$40 \%$ & 1.815 & 0.335 & 0.047 & 7.059 & 1.002 \\
$60 \%$ & 1.883 & 0.348 & 0.048 & 7.276 & 1.033 \\
$80 \%$ & 2.007 & 0.374 & 0.024 & 15.768 & 2.238 \\
\hline
\end{tabular}

Cellulase activity in monoculture $A$. niger showed the highest enzyme activity $(0.131 \mathrm{U} / \mathrm{mL})$; therefore, $A$. niger may act as a donor of cellulase enzyme within mixed culture in specific quantities. A. niger produced more extracellular cellulase contain exo- $\beta$-glucanase and $\beta^{-}$ glucosidase that significantly degrade filter paper (Kassim 1982). On the other hand, T. reesei produced more endo- $\beta$ glucanase, exo- $\beta$-glucanase, and lack of $\beta$-glucosidase
(Jamil et al. 2009). Hence, cellulase produced by mixed culture of $A$. niger and $T$. reesei were able to convert cellulose substrates into simple sugars through synergy effect of cellulase complexes produced by these two fungi (Jamil et al. 2009).

Addition of ammonium sulfate increased cellulase activity because of salting-out process. The process of salting out decreases protein solubility since salt ions were 
given in high concentrations. The exact concentration of salt allowed the separation of different proteins and precipitate them (Jamil et al. 2009). Hence, the addition of $80 \%$ ammonium sulfate in mixed culture increased the cellulase activity significantly $(\mathrm{P}<0.05)$ because its hydrophilic cellulase enzyme needs high concentration of ammonium sulfate to precipitate (Jamil et al. 2009). The less activity of cellulase in crude extract showed many undesired contaminants in crude extracts compared to partially purified enzyme (Nema et al. 2016). The specific activity of enzyme in mixed culture was improved along with the addition of the ammonium sulfate concentration that causes an increase in activity up to 2.238 folds. Hence, the combination of Aspergillus niger and Trichoderma reesei in carboxymethyl cellulose media production followed by ammonium sulfate precipitation at $80 \%$ saturation can be a promising cellulase production for highly cellulase activity

\section{ACKNOWLEDGEMENTS}

This research was supported by Directorate of Research and Community Engagement, Universitas Indonesia, PITTA 2019.

\section{REFERENCES}

Bradford MM. 1976. A rapid and sensitive method for the quantitation microgram quantities of protein utilizing the principle of protein-dye binding. Anal Biochem 72: 248-254.

Dashtban M, Maki M, Leung KT, Mao C, Qin W. 2010. Cellulase activities in biomass conversion: measurement methods and comparison. Crit Rev Biotechnol 30: 302-309. DOI: 10.3109/07388551.2010.490938

Diana A, Jacqeline, Phillipe CS. 2012. Trichoderma reesei cellulase produced by submerged versus solid state fermentations. Bull UASVM Agric 69 (2): 320-326. DOI: 10.15835/buasvmcn-agr:8780

Ghose TK. 1987. Measurement of cellulase activities. Pure Appl Chem 59 (2): 257-268.

Ikeda BR, Yamamoto T, Funatsu M. 2014. Purification and some properties of cellulases from Aspergillus niger. Agric Biol Chem 1201-1209. DOI: 10.1080/00021369.1967.10858945

Jagavati S, Rodhe V, Paritala N, Rao V. 2012. Cellulase production by coculture of Trichoderma sp. and Aspergillus sp. under submerged fermentation. Dyn Biochem Process Biotechnol Mol Biol 6 (1): 7983.

Jamil A, Ahmed S, Al ET. 2009. Production and purification of cellulosedegradingg enzymes from a filamentous fungus. Pak J Bot 41 (3): 1411-1419.

Johnsen HR, Krause K. 2014. Cellulase activity screening using pure carboxymethylcellulose: Application to soluble cellulolytic samples and to plant tissue prints. Int J Mol Sci 15 (1): 830-838. DOI: 10.3390/ijms 15010830

Kassim EA. 1982. Cellulase enzyme from Aspergillus niger. Microbiol Immunol 26 (6): 449-454. DOI: 10.1111/j.1348-0421.1982.tb00198.x

Kaur HP, Joshi D. 2015. Optimization of cellulase produced by fungus isolated from water. World J Pharm Pharmaceut Sci 4 (2): 521-534. www.wjpps.com

Khokhar, Ibatsam, Muhammad SH, Sobia MIM. 2012. Isolation and screening of highly cellulolytic filamentous fungi. J Appl Sci Environ Manag 16: 223-226.

Murti MW, Sudarsono MA, Suryadi H, Murti MW, Sudar-MA, Suryadi H. 2018. Isolation of cellulolytic fungi and utilization of its cellulolytic activity for microcrystalline cellulose preparation from water hyacinth (Eichhornia crassipes). Pharmacogn J 10 (6): 10821088.

Nema N, Alamir L, Mohammad M. 2016. Partial purification and molecular weight determination of cellulase from Bacillus cereus. Int Food Res J 23 (2): 894-898.

Zhang X, Zhang YP. 2013. Cellulases: Characteristics, Sources, Production, and Applications. John Wiley \& Sons, Inc., New York.

Zhao C, Deng L, Fang H. 2018. Mixed culture of recombinant Trichoderma reesei and Aspergillus niger for cellulase production to increase the cellulose-degrading capability. Biomass Bioenerg 112, 93-98. DOI: 10.1016/j.biombioe.2018.03.001 